\title{
Sugar derived from genetically modified sugarcane
}

\author{
Franco Maria LAJOLO ${ }^{1}$, Silvia Mine YOKOYAMA², Adriana CHEAVEGATTI GIANOTTO ${ }^{2 \star ~(D) ~}$
}

\begin{abstract}
Sugar is an ancient food and currently one of the most used ingredients in human nutrition and in the food industry. In tropical regions, sugar is produced mainly from sugarcane, while temperate countries produce sugar preferably from sugar beets. Due to its widespread use, the forthcoming adoption of genetically modified (GM) sugarcane varieties may raise questions about the quality and classification of the sugar produced. Here, we describe the several varieties of sugar and their specific uses and legal classifications. Regardless of whether they are produced from beet or from sugarcane and their final use, sugar consists of highly purified substances composed almost entirely from a disaccharide (sucrose) whose molecules consist of two monosaccharide residues: glucose and fructose. The differences between commercial sugar types are primarily in sucrose content (>99.00 to $99.80^{\circ} \mathrm{Z}$ ), moisture content, ICUMSA color, conductivity ashes and reducing sugar. Neither DNA nor proteins can be detected at relevant levels in the different types of sugar. Therefore, sugar from genetically modified sugarcane varieties is virtually identical to sugar produced from conventional sugarcane, and the adoption of GM sugarcane varieties should not cause any change to the current use of sugar in human nutrition and in the food industry.
\end{abstract}

Keywords: sugar; genetically modified sugarcane; risk assessment; substantial equivalence.

Practical Application: Clarification for entities working on the sugar food chain (food industries, certification bodies, traders, etc.) on the nature of sugar produced from genetically modified sugarcane varieties and its indistinguishability from sugar produced from conventional sugarcane.

\section{Introduction}

Sugar is an ancient food and currently one of the most used ingredients in human nutrition and in the food industry. Sugar is used mainly both for its sweetener and energy potential and for offering other desirable characteristics such as texture, body, stability, and volume to foods (Fani, 2011, 2014).

The history of sugar use by human nutrition dates to ancient times. Sugarcane (Saccharum officinarum) - the first known source of sugar - has its origin in New Guinea, being cultivated by humans since $8,000 \mathrm{BC}$. The first record of rudimentary sugar production dates to $2.000 \mathrm{BC}$, when the Hindus discovered that evaporating sugarcane juice in open containers could lead to the production of a sweet brown syrup that can be crystallized. The Hindus also discovered that such crystals could be used to conserve fruits. Those crystals were called sarkara, meaning grains in Sanskrit. The word sarkara gave rise to the Greek word sakcharon, which was duly Latinized by Linnaeus in 1753 to give name to the whole sugarcane genus (Cheavegatti-Gianotto et al., 2011). Sarkara is also the root of all words used currently to designate sugar: sukkar (Arabic), sugar (English), açúcar (Portuguese), zucchero (Italian), zuzcher (German), etc. (Fani, 2011)

Several civilizations improved and disseminated the sugar production to other areas over the centuries. Among the most important improvements in sugar refining is the addition of lime to filtered sugarcane juice, discovered by the Egyptians in the seventh century. After the spread of sugarcane plantations to the New World by the Portuguese and Spanish and to the islands of the Indian Ocean by the Dutch in the 16th Century, sugarcane cultures and sugar production became an important part of the global economy. That was true until the Continental Blockade decreed by Napoleon Bonaparte stopped the sugar trade in Europe in 1806. Taking advantage of a research that determined the indistinctness between sugar beet and sugarcane sugar carried out in 1747 , the Imperator started the development of the sugar beet industry in Europe (Fani, 2011). Currently, about $80 \%$ of the world sugar is produced from sugarcane and $20 \%$ is produced from sugar beets. India leads sugar production from sugarcane (35.9 million metric tons - MT) followed by Brazil (30.6 MT), while the European Union ranks in third (19.5 MT) with sugar produced from sugar beets (Burnquist et al., 2019).

Global sugar production increased from about $160 \mathrm{MT}$ in 2010/11 to 181 MT estimated for 2019/20 harvest. Similarly, sugar consumption (up for over 25 consecutive years) is expected to rise due to the growth in markets such as Egypt, India, Indonesia, and Pakistan (United States Department of Agriculture, 2019). This increase in global sugar demand challenges sugarcane and sugar beet producers to increase crop yields while fulfilling the restrictive environmental concerns of actual consumers. This can be partially achieved with the use of genetically modified crops. The adoption of biotechnology crops over the last 20 years have had a positive impact on producer income worldwide due to

${ }^{1}$ Departamento de Alimentos e Nutrição Experimental, Faculdade de Ciências Farmacêuticas, Universidade de São Paulo - USP, São Paulo, SP, Brasil

${ }^{2}$ Departamento de Assuntos Regulatórios e Governamentais, Centro de Tecnologia Canavieira, Piracicaba, SP, Brasil

*Corresponding author: adriana.gianotto@ctc.com.br 
productivity and efficiency of gains. Besides, it is estimated that the adoption of insect-resistant genetically modified crops since 1996 have reduced pesticide inputs by $8.2 \%$, or 671.2 million $\mathrm{kg}$, which led to an overall reduction in the environmental footprint of biotech crops by $18.4 \%$ (International Service for the Acquisition of Agri-biotech Applications, 2018).

In 2000, a genetically modified glyphosate-resistant sugar beet was developed by Monsanto and KWS Saat. The commercialization of this variety started in 2007 and the commercial adoption rate was booming. For instance, GM sugar beets corresponded to $60 \%$ of the sugar beets grown in the US in $2008 / 2009$ and, by $2009 / 2010$, the percentage of GM beets grown in the US raised to approximately 95\% (Dillen et al., 2013). Since then, American consumers have been consuming sugar from GM sugar beets and studies have found that the sugar from glyphosate-resistant sugar beets is molecularly identical to and so has the same nutritional value as sugar from conventional (non-GM) sugar beets (Klein et al., 1998; Oguchi et al., 2009).

Recently, CTNBio, the Brazilian Biosafety Authority granted approval for the two first GM sugarcane varieties (CTC20Bt and CTC9001BT) for cultivation and food/feed use in Brazil (Brasil, $2017,2018 \mathrm{a}$ ). Both varieties present resistance to sugarcane borer, Diatraea saccharalis. According to a USDA GAIN Report, the Ministry of Agriculture of Indonesia issued the feed safety certificate for GM drought-tolerant sugarcane in 2018, making it the first GM crop to be eligible for commercial cultivation in that country (United States Department of Agriculture, 2018a).

As sugarcane is a vegetative propagative crop, it is not expected that the adoption rate of GM varieties would be as high as for GM sugar beets. Although the real status of commercialization of these GM sugarcane varieties is yet to be seen, it is already expected that sugar produced from genetically modified sugarcane is going to reach Brazilian consumers and the Brazilian food industries soon.

This novelty has the potential to raise questions regarding the differences between sugar produced from conventional and GM sugarcane varieties and whether there will be any impact on the adoption of GM sugarcane varieties on the usage of sugar produced from them. To our knowledge this is the first review that evaluates the different types of sugar existing in the market, including their legal status, the characteristics of sucrose and the potential presence of DNA and protein from sugarcane in sugar after processing. The available information allowed us to conclude that sugars from genetically modified sugarcane are virtually identical to sugar produced from conventional sugarcane and that the adoption of GM sugarcane varieties should not cause any change to the use of sugar in human nutrition and in the food industry.

\section{The classification and quality requirements for the different types of sugar}

In Brazil, sugar production starts by extracting sugarcane juice from sugarcane stalks. Freshly produced sugarcane juice is an opaque liquid with color ranging from brownish to dark green according to the sugarcane cultivar used and the storage time (Bomdespacho et al., 2018). In Brazilian informal markets, sugarcane juice is commonly consumed in natura after pressing. The sugarcane juice can also be submitted to minimal processing for extending shelf-life up to 96 days if stored at $4{ }^{\circ} \mathrm{C}$ to avoid microbial deterioration (Geremias-Andrade et al., 2020).

In the Brazilian mills, after sugarcane juice extraction, several refining steps are employed that degrades DNA and proteins initially present in the freshly extracted juice. One of the main purifying steps is called "clarification" and consists of applying sulphur dioxide $\left(\mathrm{SO}_{2}\right)$, lime and heating for the removal of color components and the flocculation of macromolecules such as polysaccharides, DNA and macromolecules (Cheavegatti-Gianotto et al., 2011; Organization for Economic Co-operation and Development, 2011). Bernardi et al. (2019) propose that ozone can satisfactorily replace $\mathrm{SO}_{2}$ in the sugarcane juice clarification step. The processing steps result in a highly purified product (sugar) composed almost entirely of sucrose. Indeed, sugar, as defined by Normative Instruction $\mathrm{N}^{\circ} 47$ (IN 47) of August 30, 2018, of the Brazilian Ministry of Agriculture, is "[...] the product obtained from sugarcane belonging to the cultivars of Saccharum officinarum L. species through appropriate processes; is composed of crystals, with the exception of liquid sugar" (Brasil, 2018c). The IN 47 also describes the various types of sugar available in the Brazilian market according to their end use, such as sugar intended for human consumption through direct sale to the end consumer (Group I - Table 1) or sugar for food industries and other uses (Group II - Table 2).

At international level, The Codex Standard for Sugars (Food and Agriculture Organization of the United Nations, 1999, p. 1-5) describes refined white sugar intended for human

Table 1. Description of sugar belonging to Group I (sugar intended for human consumption through direct sale to the end consumer) according to Normative Instruction No. 47.

\begin{tabular}{|c|c|c|c|c|c|}
\hline \multirow[b]{2}{*}{ Classes } & \multirow[b]{2}{*}{ Types } & \multicolumn{4}{|c|}{ Parameters } \\
\hline & & $\begin{array}{l}\text { Polarization } \\
\left.\text { ( }{ }^{\circ} \mathrm{Z} \text { min. }\right)\end{array}$ & $\begin{array}{l}\text { Moisture } \\
\text { (\% max.) }\end{array}$ & $\begin{array}{l}\text { ICUMSA color } \\
\left(\mathrm{IU}^{3} \max .\right)\end{array}$ & $\begin{array}{c}\text { Conductive Ashes } \\
\text { (\% max.) }\end{array}$ \\
\hline \multirow[t]{4}{*}{ White crystal } & Cristal & 99.5 & 0.10 & $300\left(^{*}\right)$ & 0.10 \\
\hline & Refined amorphous or Refined & 99.00 & 0.30 & 100 & 0.20 \\
\hline & Refined granulated & 99.80 & 0.05 & 60 & 0.04 \\
\hline & Icing sugar & 99.00 & 0.30 & 150 & 0.20 \\
\hline \multirow[t]{3}{*}{ Raw crystal } & Demerara & 96.00 & 1.20 & 5.000 & 0.50 \\
\hline & $\mathrm{VHP}^{1}$ & 99.00 & 0.25 & 2.500 & 0.25 \\
\hline & $\mathrm{VVHP}^{2}$ & 99.49 & 0.15 & 1.000 & 0.15 \\
\hline
\end{tabular}

$\left({ }^{*}\right)$ There is a tolerance of up to 400 IU for the organic product, certified according to specific legislation; ${ }^{1}$ VHP: Very High Polarization; ${ }^{2}$ VVHP: Very Very High Polarization. ${ }^{3}$ ICUMSA Units. 
Table 2. Description of sugar belonging to Group II (sugar for food industries and other uses) according to Normative Instruction No. 47.

\begin{tabular}{|c|c|c|c|c|c|c|}
\hline \multirow[b]{2}{*}{ Classes } & \multirow[b]{2}{*}{ Types } & \multicolumn{5}{|c|}{ Parameters } \\
\hline & & $\begin{array}{c}\text { Polarization } \\
\left({ }^{\circ} \mathrm{Z} \text { min. }\right)\end{array}$ & $\begin{array}{l}\text { Moisture } \\
(\% \text { max. })\end{array}$ & $\begin{array}{l}\text { ICUMSA color } \\
\left(\mathrm{IU}^{3} \mathrm{max} .\right)\end{array}$ & $\begin{array}{l}\text { Conductive Ashes } \\
\text { (\% max.) }\end{array}$ & $\begin{array}{c}\text { Reducing sugars } \\
\text { (\% m/m max.) }\end{array}$ \\
\hline \multirow[t]{3}{*}{ White } & Crystal & 99.5 & 0.10 & $300\left(^{*}\right)$ & 0.10 & N/A \\
\hline & Icing sugar & 99.00 & 0.30 & 150 & 0.20 & N/A \\
\hline & Refined granulated & 99.80 & 0.05 & 60 & 0.04 & N/A \\
\hline Raw & VVHP $^{2}$ & 99.49 & 0.15 & 1.000 & 0.15 & N/A \\
\hline \multirow[t]{2}{*}{ Liquid } & Liquid & N/A & N/A & 120 & 0.30 & 0.30 \\
\hline & Inverted & N/A & N/A & 120 & 0.30 & 60 to 90 \\
\hline
\end{tabular}

$\left.{ }^{*}\right)$ There is a tolerance of up to 400 IU for the organic product, certified according to specific legislation; ${ }^{1}$ VHP: Very High Polarization; ${ }^{2}$ VVHP: Very Very High Polarization. ${ }^{3}$ ICUMSA units; N/A = Does not apply.

consumption as "[...] purified and crystallized sucrose (sucrose) with a polarization of not less than $99.7^{\circ} \mathrm{Z}$ ". The Organization for Economic Co-operation and Development (OECD) states that white refined sugar typically contains about $99.93 \%$ of sucrose, with small content of water, invert sugar or reducing sugars (glucose and fructose), ashes, color components and other organic compounds (Clarke, 1988). The OECD clarifies that, although these impurities are less than $0,1 \%$ of the sugar content, they can affect the sugar quality and its behavior during storage (Van der Poel et al., 1998). The OECD acknowledges that the sucrose content of raw sugar varies but is mainly in the range of 97 to $99.5 \%$ sucrose (Organization for Economic Co-operation and Development, 2011).

None of the classifications mentioned above mentions DNA or protein contents as being relevant to the composition, classification, or determination of the sugar quality. It is understood, therefore, that these three independent agencies consider that the DNA and protein contents are irrelevant in the evaluation of the composition of the different types of sugar. This is noteworthy as protein and DNA are the only expected potential differences among sugar derived from GM and conventional sugarcane varieties. It is especially important to evaluate whether there would be any relevant difference among sugar produced from GM sugarcane varieties and sugar from conventional sugarcane according to the Principle of Substantial Equivalence (Organization for Economic Co-operation and Development, 1993). This concept includes both toxicological and nutritional safety aspects and stands that, if a new food is found to be substantially equivalent to an existing one, it can receive the same treatment regarding to safety (World Health Organization, 1995).

\section{The physicochemical characteristics of the sucrose molecule}

Despite its classification or final use, sugar is a highly purified substance composed almost entirely from sucrose. Easy to obtain, inexpensive and non-toxic, sugar (sucrose) is a highly purified substance composed of carbon $(\mathrm{C})$, hydrogen $(\mathrm{H})$ and oxygen $(\mathrm{O})$, namely a carbohydrate. Currently, it is known that sucrose is a disaccharide, whose molecule consists of two monosaccharide residues: glucose and fructose (Figure 1). Its chemical formula is $\mathrm{C}_{12} \mathrm{H}_{22} \mathrm{O}_{11}$ with a molar mass of $342.3 \mathrm{~g} / \mathrm{mol}$.

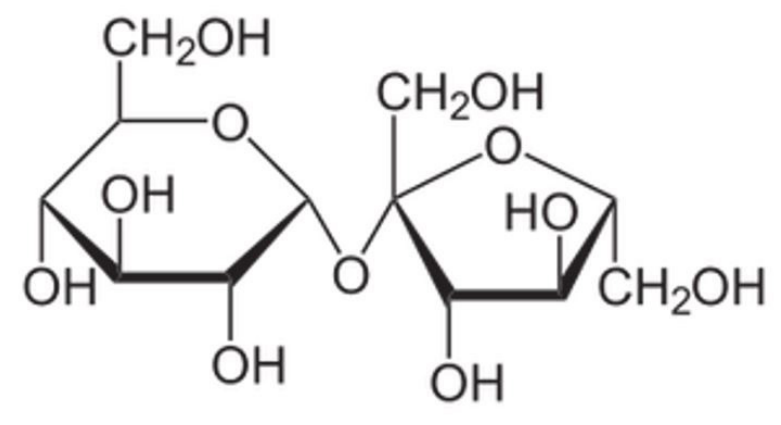

Figure 1. Sucrose molecular structure.

In crystallized state, pure sucrose presents as colorless and odorless crystals. In optimal conditions, it crystallizes in the form of a 15-facet anhydrous prism, whose symmetry axes are slightly inclined. However, these perfect crystals are rarely found. In a small grain of sugar observed with a magnifying glass, or in a giant crystal, only 8 to 10 facets are normally observed. A dry-heated sugar crystal begins to melt at around 160 to $170^{\circ} \mathrm{C}$, with an exact melting point of $186^{\circ} \mathrm{C}$. Above this temperature, it begins to form caramelized compounds (Fani, $2011,2014)$. The purity of sucrose is measured by polarimetry, through the rotation of plane-polarized light by a solution of sugar. The specific rotation at $20^{\circ} \mathrm{C}$ using yellow "sodium-D" light $(589 \mathrm{~nm})$ is $+66.47^{\circ}$. Commercial samples of sugar are tested using this parameter (Desai et al., 2013).

Therefore, the sucrose molecule is a structural unit of fixed composition, from which it follows that it also presents invariable physical/chemical properties, such as density, melting point, boiling point, etc. That said, it is not even reasonable to expect that these molecule properties may vary depending on the source used as raw material to produce sugar.

\section{The biosynthesis of the sucrose molecule}

In nature, sucrose is synthesized by photosynthesizer organisms such as plants and cyanobacteria. Many plants store sucrose in their organs, primarily stalks, roots, fruits, 
and nectars, because, along with starch, it enables the storage of energy from photosynthesis. Therefore, in most plant cells, triose phosphates produced during $\mathrm{CO}_{2}$ fixation are converted into sucrose and/or starch. The balance between these processes is tightly regulated, and both processes must be coordinated with the rate of carbon fixation. Unlike starch, sucrose is soluble and can be translocated within the plant as a soluble carbohydrate via the phloem, serving as a signaling molecule that triggers essential metabolic events (Maloney et al., 2015). In addition to that, the sucrose molecule is produced in a well-known metabolic pathway in plants (Figure 2). The synthesis of sucrose has been well characterized in plants and microbes and involves a two-step process catalyzed by sucrose-6-phosphate synthase (SPS; EC 2.4.1.14) and sucrose-6-phosphate phosphatase (SPP; EC 3.1.3.24). It was shown that these enzymes interact in planta and promote plant growth and biomass accumulation (Maloney et al., 2015).

No change in sucrose production is expected if there is no change in the pathway of sucrose production in genetically modified plants. This premise is true for, at least, the first generation of genetically modified plants that have insect resistance characteristics. Genes with these characteristics are not part of and are not expected to affect the metabolic pathway shown in Figure 2.

Additionally, Biosafety authorities worldwide require the demonstration of no unintended change of nutritional parameters in GM sugarcane cultivars compared to conventional counterparts prior to commercial approval according to the Substantial Equivalence Principle. The Organization for Economic Co-operation and Development (2011) expressly recommends the assessment of sucrose levels in the stalks of new varieties of sugarcane intended for food and feed use. Thus, the two first GM sugarcane varieties that are entering the Brazilian market - CTC20Bt and CTC9001BT - did not present changes in sucrose levels compared to their conventional counterparts (Cheavegatti-Gianotto et al., 2018, 2019). These results were considered by the CTNBio on its technical opinion on food and feed safety for these GM varieties (Brasil, 2017, 2018a).

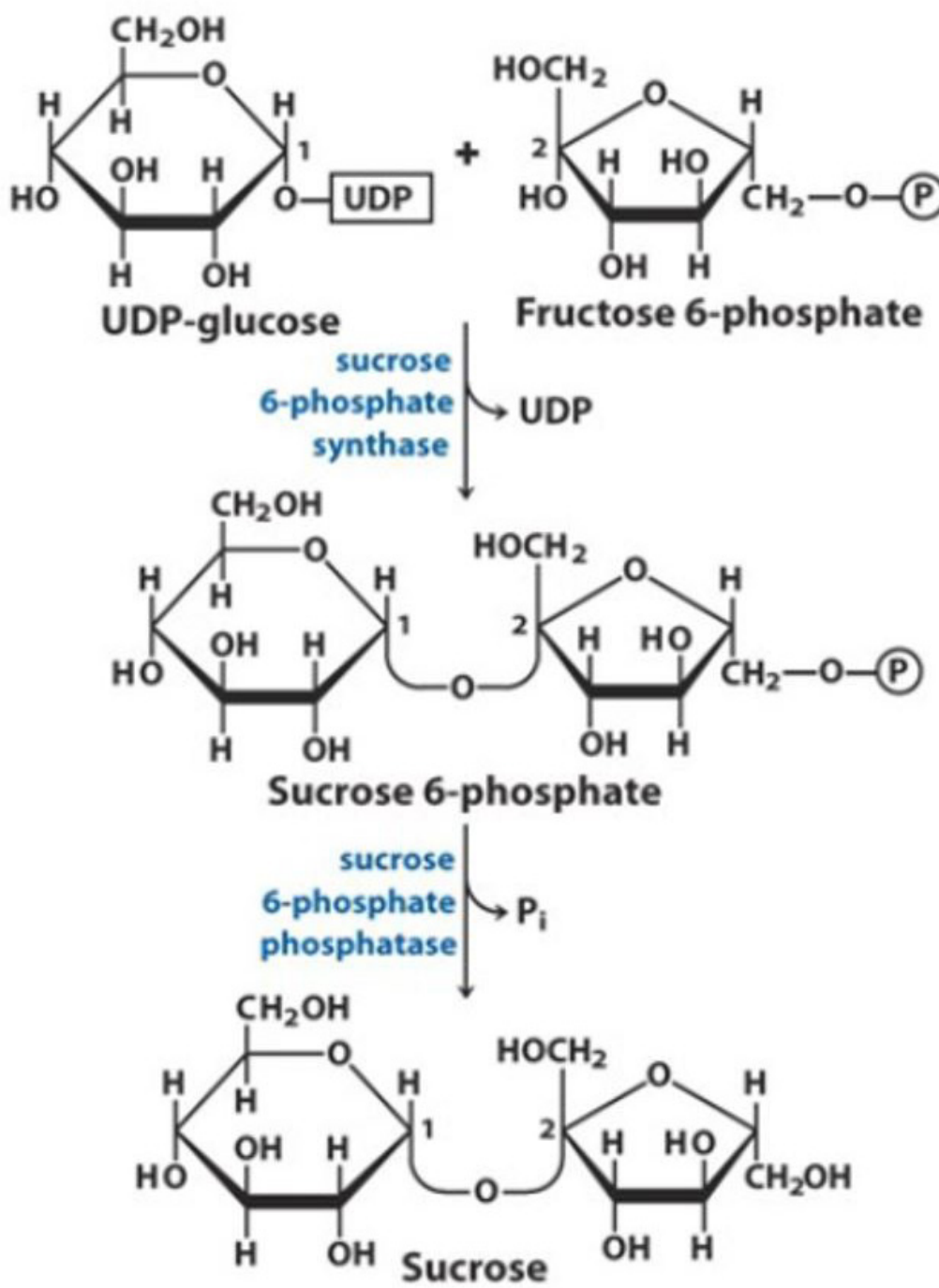

Figure 2. Sucrose synthesis pathway. 


\section{The assessment of the presence of DNA and protein in sugar}

Despite the absence of specific standards for DNA and protein contents in sugar, several independent research groups have addressed the question of whether these molecules are present in sugar and whether the origin of the raw material, especially if genetically modified, influenced the content of these substances in raw and/or refined sugar.

The first experiments conducted to assess the presence of DNA and protein in sugar assessed the presence of these substances in sugar produced from sugar beets. Klein et al. (1998) verified that sugar obtained from conventional and transgenic sugar beets were indistinguishable, in other words, that those types of sugar were substantially equivalent with respect to purity. These findings were later supported by Oguchi et al. (2009), that concluded that sugar beet DNA was degraded at an early stage of sugar processing and that no PCR amplification was detected from the investigated sugar products either because of low DNA recovery and/or PCR inhibition.

The presence of DNA and proteins in sugar produced from sugarcane was also assessed. Cullis et al. (2014) assessed the presence of DNA and protein in sugar produced from conventional sugarcane in the Brazilian mills. The authors concluded that retail-purchased refined sugarcane sugar showed no detectable protein or DNA at the levels of the assays $(<2 \mathrm{ppm}$ of protein; $0.001 \mathrm{ppm}$ of DNA). Joyce et al. (2013) were the first to assess the presence of introduced DNA and protein in sugar produced from genetically modified sugarcane. The results of their study indicated that sugar crystallized from GM sugarcane plants did not contain residual DNA or proteins of the introduced transgenes using conventional molecular techniques.

The presence of foreign DNA and protein in sugar produced from the two GM sugarcane cultivars already approved by CTNBio to be planted in Brazil were also accessed. DNA and protein were not detected in the clarified juice and downstream processed fractions of CTC20BT, including ethanol and raw sugar, indicating that protein and DNA are removed and/or degraded during the processing of this GM variety (Cheavegatti-Gianotto et al., 2018). Similarly, and not surprisingly, neither DNA nor protein was detected at significant levels in sugar produced from the CTC9001BT variety (Cheavegatti-Gianotto et al., 2019).

It should be noted that these works were conducted with very specific and sensitive methodologies for the detection of DNA and protein contents in sugars according to the LODs (Limit of Detection) and LOQ (Limit of Quantification) reported. The levels of LOD and LOQ reported in these studies are low enough to allow us to conclude that, if present, the levels of DNA and proteins in sugar are negligible from the food exposure standpoint.

\section{The classification of sugar from genetically modified sugarcane according to CTNBio}

In Brazil, CTNBio is the Biosafety authority in charge to clarify any questions related to genetically modified organisms and their derivatives. The AGROBIO (Association of Biotechnology Companies in Agriculture and Agroindustry) specifically questioned CTNBio whether, because of its intrinsic purity, sugar produced from genetically modified sugarcane should be classified as a "chemically defined pure substance" as set forth in Law 11,105. The opinion of CTNBio was published in the Brazilian Official Gazette through Technical Opinion No. 5.837/2018 (Brasil, 2018b). Due to its clarity, it is transcribed (translated) below:

The description of the product "sugar" contained in the inquiry, allows for its qualification as a "[...] pure chemically defined substance" according to the paragraph 4, article 3, of Law 11,105/2005, since the absence of recombinant DNA and viable organism in the product was proven;

As a consequence of this qualification, we concluded that this "sugar" product does not fall within the scope of the Biosafety Law, in its 1st article, and is not a GMO neither a GMO derivative, as set forth in its article 3.

At its 210th ordinary meeting, CTNBio unanimously concluded that the product "sugar" produced from genetically modified substance is a "[...] pure, chemically defined substance" according to paragraph 2, article 3, of the Biosafety Law.

Although the "chemically defined pure substance" concept is exclusive to the Brazilian Biosafety Law, other countries have similar classification for highly purified ingredients. For instance, the US Department of Agriculture (USDA) recently published a National Bioengineered Food Disclosure Standard (NBFDS) to regulate the mandatory labeling of food produced from GM crops. In this Standard, the USDA classification defines "Bioengineered Food" as food "[...] that contains genetic material that has been modified through in vitro recombinant deoxyribonucleic acid (DNA) techniques"; and "[...] for which the modification could not otherwise be obtained through conventional breeding or found in nature". According to this definition, the USDA expressly stated that sugar from either GM sugarcane or sugar beets cannot be classified as Bioengineered Foods and are, therefore, exempted from the mandatory labeling requirement for Bioengineered Foods (United States Department of Agriculture, 2018b, p. 65833 - 65835).

Based on the available scientific evidence, several other countries (e.g. Australia, Japan, Israel, New Zealand, and South Korea) have also exempted refined sugar from their respective GM food labeling requirements (United States Department of Agriculture, 2018b).

\section{Conclusion}

Despite their classification for end use, sugars are highly purified substances, basically consisting of sucrose. The impurities present in the sugar are basically moist, reducing sugars, ashes, and compounds that give its coloration. The levels of DNA and proteins in sugar are not detectable by the current methodologies and, if present, are found in negligible amounts. So, today,no regulatory agency in the world considers them relevant for the determination of quality and/or classification of sugar. According to that, regulatory agencies worldwide have been classified sugar as a pure substance (or similar concept), exempting sugar from 
the precautionary safety requirements of GM crops and GM derived foods. Consequently, sugar produced from genetically modified sugarcane should be considered absolutely identical to sugar produced from conventional sugarcane and should not suffer any kind of differentiation.

In this sense, it must be considered that sugar is such a purified product that its quality does not depend on the variety used for its production. Recent estimates indicate that sugarcane has approximately 40,000 genes (Nascimento et al., 2019). As a result, the varieties currently planted may differ in tens of thousands of genes, and even then, after processing, the sugar produced from these varieties is virtually identical and marketed as the same. Thus, it is not even reasonable to imagine that the sugar produced from genetically modified sugarcane in only a couple of genes will produce a sugar that is completely different from the other conventional varieties.

\section{References}

Bernardi, R., Jorge, L. M. M., \& Paraiso, P. R. (2019). Kinetic modeling of sugarcane juice clarification by ozonation in batch reactor with ozone saturation control. Food Science and Technology, 39(Suppl. 1), 81-84. http://dx.doi.org/10.1590/fst.35417.

Bomdespacho, L. Q., Silva, B. T. R., Lapa-GUIMARÃES, J., Ditchfield, C., \& Petrus, R. R. (2018). Cultivar affects the color change kinetics of sugarcane juice. Food Science and Technology, 38(Suppl. 1), 96102. http://dx.doi.org/10.1590/fst.15017.

Brasil, Comissão Técnica Nacional de Biossegurança - CTNBio. (2017, June 27). Extrato de parecer técnico no 5.483/2017. Diário Oficial [da] República Federativa do Brasil.

Brasil, Comissão Técnica Nacional de Biossegurança - CTNBio. (2018a, December 17). Extrato de parecer técnico no 6.235/2018. Diário Oficial [da] República Federativa do Brasil.

Brasil, Comissão Técnica Nacional de Biossegurança - CTNBio. (2018b, March 28). Extrato de parecer técnico n 5.837/2018. Diário Oficial [da] República Federativa do Brasil.

Brasil, Ministério da Agricultura, Pecuária e Abastecimento - MAPA. (2018c, September 6). Instrução normativa no 47, de 30 de agosto de 2018. Diário Oficial [da] República Federativa do Brasil.

Burnquist, H. L., Afonso, M. C., Michelin, S. C., Maielli, A. B., \& Vizioli, B. (2019). Açúcar/Perspec 2019: além de estoque e consumo, em 2019, preços estarão à mercê do petróleo. Piracicaba: USP. Retrieved from https://www.cepea.esalq.usp.br/br/releases/acucar-perspec-2019alem-de-estoque-e-consumo-em-2019-precos-estarao-a-mercedo-petroleo.aspx

Cheavegatti-Gianotto, A., Abreu, H. M., Arruda, P., Bespalhok, J. C. Fo., Burnquist, W. L., Creste, S., di Ciero, L., Ferro, J. A., Oliveira Figueira, A. V., Sousa Filgueiras, T., Grossi-de-Sá, M. D., Guzzo, E. C., Hoffmann, H. P., Andrade Landell, M. G., Macedo, N., Matsuoka, S., Castro Reinach, F., Romano, E., Silva, W. J., Castro Silva, M. Fo., \& César Ulian, E. (2011). Sugarcane (Saccharum X officinarum): a reference study for the regulation of genetically modified cultivars in Brazil. Tropical Plant Biology, 4(1), 62-89. http://dx.doi.org/10.1007/ s12042-011-9068-3. PMid:21614128.

Cheavegatti-Gianotto, A., Gentile, A., Oldemburgo, D. A., Merheb, G. D. A., Sereno, M. L., Lirette, R. P., Ferreira, T. H. S., \& de Oliveira, W. S. (2018). Lack of Detection of Bt sugarcane Crylab and NPTII DNA and Proteins in sugarcane processing products including raw sugar. Frontiers in Bioengineering and Biotechnology, 6, 24. http:// dx.doi.org/10.3389/fbioe.2018.00024. PMid:29637070.
Cheavegatti-Gianotto, A., Rocha, M. S., Cutri, L., Lopes, F. C., Dal'Acqua, W., Hjelle, J. J., Lirette, R. P., Oliveira, W. S., \& Sereno, M. L. (2019). The insect-protected CTC91087-6 sugarcane event expresses Cry1Ac protein preferentially in leaves and presents compositional equivalence to conventional sugarcane. GM Crops and Food: Biotechnology in Agriculture and the Food Chain, 10(4), 208-219. http://dx.doi.org/ 10.1080/21645698.2019.1651191. PMid:31431143.

Clarke, M. A. (1988) Sugarcane processing: raw and refined sugar manufacture. In M. A. Clarke \& M. A. Godshall (Eds.), Chemistry and processing of sugar beet and sugarcane (pp. 162-175). Amsterdam: Elsevier Science. http://dx.doi.org/10.1016/B978-0-444-430205.50017-5.

Cullis, C., Contento, A. L., \& Schell, M. A. (2014). DNA and protein analysis throughout the industrial refining process of sugar cane. Irish Journal of Agricultural and Food Research, 3(2)

Desai, H., Sevak, M., Panchal, V., Panchal, K., \& Patel, N. (2013). A new polarimetric method for the analysis of sucrose - in iron sucrose raw material, iron sucrose injection and in process bulk formulations. International Journal of Pharmaceutical Sciences and Research, 4(8), 3208-3213.

Dillen, K., Demont, M., Tillie, P., \& Rodriguez Cerezo, E. (2013). Bred for Europe but grown in America: the case of GM sugar beet. New Biotechnology, 30(2), 131-135. http://dx.doi.org/10.1016/j. nbt.2012.11.004. PMid:23207648.

Fani, M. (2011). A evolução do açúcar. Aditivos \& Ingredientes, 82, 30-40. Retrieved from https://aditivosingredientes.com.br/upload_ arquivos/201605/2016050811537001464176838.pdf

Fani, M. (2014). As múltiplas aplicações do açúcar. Aditivos \& Ingredientes, 109, 34-41. Retrieved from https://aditivosingredientes.com.br/ upload_arquivos/201605/2016050414999001462130858.pdf

Food and Agriculture Organization of the United Nations - FAO, Codex ALIMENTARIUS. (1999). CODEX STAN 212-1999: codex standard for sugars. Rome: FAO. Retrieved from http://www.fao.org/input/ download/standards/338/CXS_212e_u.pdf

Geremias-Andrade, I. M., Rocheto, A. C., Gallo, F. A., \& Petrus, R. R. (2020). The shelf life of standardized sugarcane juice stored under refrigeration. Food Science and Technology, 40(1), 95-101. http:// dx.doi.org/10.1590/fst.33918.

International Service for the Acquisition of Agri-biotech Applications - ISAAA. (2018). Pocket K no 5: documented benefits of GM crops. The Philippines: ISAAA. Retrieved from https://www.isaaa.org/ resources/publications/pocketk/5/default.asp

Joyce, P. A., Dinh, S. Q., Burns, E. M., \& O'Shea, M. G. (2013). Sugar from genetically modified sugarcane: tracking transgenes, transgene products, and compositional analysis. International Sugar Journal, 115(1380), 864-867.

Klein, J., Altenbuchner, J., \& Mattes, R. (1998). Nucleic acid and protein elimination during the sugar manufacturing process of conventional and transgenic sugar beets. Journal of Biotechnology, 60(3), 145-153. http://dx.doi.org/10.1016/S0168-1656(98)00006-6. PMid:9608751.

Maloney, V. J., Park, J. Y., Unda, F., \& Mansfield, S. D. (2015). Sucrose phosphate synthase and sucrose phosphate phosphatase interact in planta and promote plant growth and biomass accumulation. Journal of Experimental Botany, 66(14), 4383-4394.

Nascimento, L. C., Yanagui, K., Jose, J., Camargo, E. L. O., Grassi, M. C. B., Cunha, C. P., Bressiani, J. A., Carvalho, G. M. A., Carvalho, C. R., Prado, P. F., Mieczkowski, P., Pereira, G. A. G., \& Carazzolle, M. F. (2019). Unraveling the complex genome of Saccharum spontaneum using polyploid gene assembler. DNA Research, 26(3), 205-216. http:// dx.doi.org/10.1093/dnares/dsz001. PMid:30768175. 
Oguchi, T., Onishi, M., Chikagawa, Y., Kodama, T., Suzuki, E., Kasahara, M., Akiyama, H., Teshima, R., Futo, S., Hino, A., Furui, S., \& Kitta, K. (2009). Investigation of residual DNAs in sugar from sugar beet (Beta vulgaris L.). food hygiene and safety science. Shokuhin Eiseigaku Zasshi, 50(1), 41-46. http://dx.doi.org/10.3358/shokueishi.50.41. PMid:19325225.

Organization for Economic Co-operation and Development - OECD. (1993) Safety evaluation of foods derived by modern biotechnology: concepts and principles. Paris: OECD.

Organization for Economic Co-operation and Development - OECD. (2011). Consensus document on compositional considerations for new varieties of sugarcane (Saccharum ssp. hybrids): key food and feed nutrients, anti-nutrients and toxicants (Series on the Safety of Novel Foods and Feeds, No. 23). Paris: OECD. Retrieved from https:// www.oecd.org/env/ehs/biotrack/48962816.pdf

United States Department of Agriculture - USDA. (2018a). Indonesia Agricultural Biotechnology Annual 2018, GAIN report number ID1838. Washington: USDA. Retrieved from https://apps.fas.usda.gov/
newgainapi/api/report/downloadreportbyfilename?filename=Agricult ural\%20Biotechnology\%20Annual_Jakarta_Indonesia_12-13-2018.pdf

United States Department of Agriculture - USDA. (2018b). 7 CFR Part 66: national bioengineered food disclosure standard. Washington: USDA. Retrieved from https://www.govinfo.gov/content/pkg/FR2018-12-21/pdf/2018-27283.pdf

United States Department of Agriculture - USDA. (2019). Sugar: world markets and trade. Washington: USDA. Retrieved from https://apps. fas.usda.gov/psdonline/circulars/sugar.pdf

Van der Poel, P. W., Schiweck, H., \& Schwartz, T. (1998). Sugar technology: beet and cane sugar manufacture. Berlin: Verlag Dr. Albert Bartens KG.

World Health Organization - WHO. (1995). Application of the principles of substantial equivalence to the safety evaluation of foods or food components from plants derived by modern biotechnology: report of a WHO workshop. Geneva: WHO. Retrieved from https://apps. who.int/iris/handle/10665/58909 